\title{
The Composition of the Rahab Story
}

From the fourth century CE, and increasingly in the sixth and seventh centuries, Christian pilgrims began visiting the Holy Land with the express aim of finding Rahab's house in Jericho. ${ }^{\mathrm{I}}$ While the search has long since been abandoned, a number of influential scholars over the past century - including Ernst Sellin, Albrecht Alt, Martin Noth, Volkmar Fritz, Klaus Bieberstein, Ed Noort, and Michael Coogan - have argued, or assumed, that the author(s) of the account knew of a population group that traced itself to Rahab and resided near Jericho. These "Rahabites" are said to have fabricated a legend about their eponymous ancestor's bravery and her contribution to Israel's conquest of Canaan. Likewise, the Rahab story in Joshua is said to have originated as an explanation of why this particular clan of Canaanites became members of Israel in blatant contradiction to Deuteronomy's command to annihilate all the land's inhabitants.

There's a problem with this thesis: the figure of Rahab is not associated with any particular group or clan in the biblical corpus. Admittedly, a number of cities bear a similar name, yet we lack a good reason to connect them to Rahab. ${ }^{2}$ In Gentile Impurities and Jewish Identities, Christine Hayes links Rahab to the Rechabites whom the prophet Jeremiah praises (Jer. 35), but the identification is improbable: In

${ }^{\mathrm{I}}$ H. Donner, Pilgerfahrt ins Heilige Land: Die ältesten Berichte christlicher Palästinapilger (4.-7. Jahrhundert), 2nd ed. (Stuttgart: Katholisches Bibelwerk, 2003).

${ }^{2}$ For example, Rehov, Rehavat Ir, or modern Rehavia; see also Neh. 7:4, which provides an important clue to the origins of Rahab's name (lit. wide/open; similarly, rehob means open space, plaza, street). 
Hebrew, "Rahab" is not spelled the same way as "Rechab," and it has a different meaning and etymology. ${ }^{3}$

Scholars who read the story as an apologia for the "Rahabites" usually rely on the statement in Joshua 6:25 that "she/it still dwells in the midst of Israel until the present day." Although "her family" may be an implicit subject of the verb "dwell" in the Hebrew, and although many translators make this explicit, it is clear from the next line that the subject must be Rahab. The statement is not meant to be taken literally; nothing is being said here about a particular population group. ${ }^{4}$

Instead of understanding Rahab as the eponymous ancestor of an ancient clan (similar to Caleb and the Calebites), we would be better served by interpreting her as a paradigmatic Other. Just as she came to be the prototypical proselyte for the rabbis, she figures in the biblical account as an archetypal outsider who successfully achieves membership among the people of Israel. Inasmuch as she is not associated with any one clan or community, this liminal figure from Canaanite society could serve as a safe proxy for outsiders from various times and places.

The use of legends as arguments for tolerance is an abiding feature of historical fiction through the ages. (For example, Jean Racine's lesserknown play featuring the biblical queen Esther from I 689 was read as an apology for religious tolerance and a polemic against the revocation of the Edict of Nantes. ${ }^{5}$ ) Of central importance to our study of war commemoration and national identity, the biblical legend links Rahab's continued presence "in the midst of Israel" to her contributions at a defining moment in the wars of conquest: "for she hid the messengers whom Joshua sent to spy out Jericho" (Josh. 6:17, 25). The account sets forth a principle of inclusion, one that Rahab illustrates through both words and deeds.

\section{THE RAHAB STORY AS A NARRATIVE FRAME}

The Rahab story is delivered in two installments. The first episode is found in chapter 2 and portrays her saving the spies; the second episode appears at the end of chapter 6, where the spies save Rahab and her family. In the narrative of Joshua, these two episodes bracket a foundational period of

${ }^{3}$ Hayes, Gentile Impurities, $2 \mathrm{I}$.

${ }_{4}$ As we saw in Chapter 7, the rabbis discovered clues in scripture indicating that Rahab was rewarded with an honorable status in Israelite society and became the ancestress of many national leaders; unlike modern scholars, however, they didn't understand Rahab to be the eponymous ancestor of a group that called themselves "Rahabites."

5 See René Jasinski, Autour de l'Esther racinienne (Paris: Nizet, I985). 
miraculous triumph, which commences with the crossing of the Jordan and concludes with the conquest of Jericho. ${ }^{6}$ At a time of the year when the Jordan was most dangerous to ford, the Israelites cross on dry ground. They mark the crossing with a number of ritual-commemorative activities: construction of a monument with stones from the Jordan; circumcision of the males; celebration of the Passover; and cessation of manna and consumption of crops in Canaan. Portrayed as a divine triumph over the inimical forces of chaos, the desiccation of the Jordan mirrors the crossing of the Red Sea, on the one hand, and anticipates the miraculous collapse of Jericho's walls, on the other. ${ }^{7}$ In contrast to these events, the subsequent subjugation of $\mathrm{Ai}$ is achieved through natural means (a clever stratagem), and the nation must first suffer devastating defeats:

\section{The Rahab Story in Joshua I-8}

Chapter I: Yhwh's marching orders to Joshua

Chapter 2: Rahab saves the spies

Chapters 3-4: Crossing of the Jordan

Chapter 5: Rituals celebrating transition to the promised land

Chapter 6: Conquest of Jericho, with the spies saving Rahab

Chapters 7-8: Battle of Ai, which begins with Israel's defeat

The section of the narrative framed by the Rahab story devotes disproportionate attention to the cult. The river recedes when the priests bearing the ark enter it, and the walls of Jericho fall when seven priests marching with the ark blow their seven shofars. This material likely represents the work of priestly scribes at the Jerusalem temple who revised an older, much shorter report of the crossing of the Jordan and conquest of Jericho. In this new and improved edition of the account, cultic personnel and paraphernalia play an indispensable role. In stark contrast to the narrative it frames, the Rahab story commemorates the contributions of a Canaanite prostitute and declares that she later enjoyed a place of honor in Israel's midst (6:25). Undoubtedly, the account of this pivotal moment in the nation's past would have scandalized priestly sensibilities. We know from numerous Pentateuchal texts that priests were highly anxious about the camp's purity, and it was presumably a scribe of

${ }^{6}$ Similarly, the Song of Deborah, together with the Song of the Sea from the book of Exodus, demarcates "bookends" around a special epoch of Yhwh's activity within the national narrative; see the discussion in Chapter Io.

7 The link is made explicit in the formulation of Rahab's words about Egypt in 2:9-I I and the narrator's statement about the Jordan in 5:I. Notice how Psalms I I 4 synthesizes the two events. 
priestly pedigree who made sure to point out that when the spies rescued Rahab and her family, they placed them outside "the camp of Israel" $(6: 23) .^{8}$

\section{THE PLACE OF THE RAHAB STORY IN THE NARRATIVE}

The book of Joshua begins with the nation's new leader commanding the officers to prepare the nation for the crossing of the river, which will take place "in three days":

Joshua commanded the officers of the people, "Pass through the camp and command the people: 'Prepare your provisions; for in three days you are to cross over the Jordan, to go in and take possession of the land that Yhwh your god is giving you to possess." (I:IO-II)

We encounter this same group of officers at the Jordan crossing, which is said explicitly to have occurred precisely after this time period:

After three days the officers went through the camp and commanded the people, "When you see the ark of the covenant of Yhwh your god being carried by the levitical priests, then you shall set out from your places and follow after it ...." $(3: 2-3)$

The similar formulations in these two passages have misled some scholars to assume that they form an older running narrative into which the Rahab story was inserted at a later point. ${ }^{9}$ The interpretation does not hold up to scrutiny: In the first passage the officers are to pass through the camp immediately and command the people to prepare for the Jordan crossing three days from then, while in the second passage the officers wait three days before marching through the camp and issuing orders to the people. Instead of forming a coherent, older narrative thread, the two texts actually contradict each other, and the opposite compositional scenario suggests itself: what we have here is a later scribal attempt to synthesize the Rahab story with the later narrative of the Jordan crossing, with the

${ }^{8}$ On many of the passages from Joshua discussed in this chapter and Chapter 9, see Farber, Images of Joshua, as well as the commentary by Dozeman, Joshua I-I 2.

9 This interpretation assumes that the description of the Jordan-crossing is an older part of the narrative; see Carl Steuernagel, Übersetzung und Erklärung der Bücher Deuteronomium und Josua und allgemeine Einleitung in den Hexateuch (Göttingen: Vandenhoeck \& Ruprecht, I900); and, more recently, Erhard Blum, "Überlegungen zur Kompositionsgeschichte des Josuabuches" in Ed Noort (ed.), The Book of Joshua (Leuven: Peeters, 2012), I37-I 57; as well as Joachim J. Krause, Exodus und Eisodus: Komposition und Theologie von Josua I-5 (Leiden: Brill, 20I4), I97-274. 
formulation "in/after three days" implying the exact duration of the reconnaissance mission (see $2: 16,22$ ). ${ }^{10}$

The Rahab story appears both to be older than the narrative of the Jordan crossing, and to have grown in stages to its present proportions. According to my analysis, its earliest iteration told the backstory to the battle of Jericho and was prefaced directly to it. Both the Rahab story and the battle account represent older portions of chapters $\mathrm{I}-7$, and they gradually drifted apart as later scribes composed the disparate materias related to the crossing of the Jordan in chapters $3-5 .{ }^{\mathrm{II}}$

The Rahab story was composed for, and added directly to, the battle account in chapter 6 . As we shall see, it was originally much shorter and did not necessitate the follow-up episode in chapter 6. Recently, Joachim Krause has taken a different approach, arguing that the Rahab story is relatively unified and represents a late development in an older narrative of the Jordan crossing in chapters $\mathrm{I}-5 .{ }^{\mathrm{I} 2}$ However, we can more easily explain the literary evidence if we accept I) that the Rahab story originated as an early preface to the account of the Jericho battle, and 2) that the narrative of the Jordan crossing in chapters $\mathrm{I}-5$ represents a later compositional stage.

With regard to the second episode of the Rahab story in chapter 6, the battle account reads more smoothly without the lines related to Rahab; not surprisingly, scholars have long declared them to be supplementary. Below, I have arranged the text to show how the Rahab story presupposes redactions of the battle account. As in the narrative of the Jordan crossing, one redaction assigns an indispensable role to the priests and their trumpets, while, in keeping with the Deuteronomistic program of destruction (herem), another redaction develops the description of the city's demolition. The oldest substratum of this section is in boldface, while the later lines related to Rahab are indented. Even

ro How these older parts of the book of Joshua came to be connected to the exodus account is an important issue that deserves separate treatment. One possibility presents itself in Joshua 3:I: "They set out from Shittim and came to the Jordan. ... They stayed the night there before crossing over." While all of chapter I appears to be later, the paragraph in verses IO-I I is likely its oldest section.

That the conquest begins with the crossing of the Jordan rather than from the south (as we would expect for the account of Israel coming up from Egypt) is a major problem, one that is explained variously in the Pentateuch; see Wright, David, King of Israel, I94-I97.

${ }^{\text {II }}$ A portion of the account of the battle of $\mathrm{Ai}(8: 3-29)$ seems to be older, and, when appending it to the narrative, scribes expanded it with themes from the preceding chapters.

${ }^{\text {I2 }}$ See Krause, Exodus und Eisodus, as well as Blum, "Überlegungen." 
though the latter are not differentiated below, they likely do not all stem from the same hand.

\section{Compositional Strata in Joshua 6:14-26}

I $4 \ldots$ on the second day they marched around the city once and then returned to the camp. They did this for six days. ${ }_{5}$ On the seventh day they rose early, at dawn, and marched around the city in the same manner seven times. It was only on that day that they marched around the city seven times. 16 And the seventh time, when the priests had blown the trumpets, Joshua said to the people, "Shout! For Yhwh has given you the city.

I7 The city and all that is in it shall be devoted to Yhwh for destruction.

Only Rahab the prostitute and all who are with her in her house shall live, because she hid the messengers we sent.

I 8 As for you, keep away from the things devoted to destruction, so as not to covet and take any of the devoted things and make the camp of Israel an object for destruction, bringing trouble upon it.

I9 But all silver and gold, and vessels of bronze and iron, are sacred to Yhwh; they shall go into the treasury of Yhwh."

20 So they raised - the trumpets were blown; when the people heard the sound of the trumpets, they raised - a great shout, and the wall fell down flat. Thereafter the people charged straight ahead into the city and captured it.

2I They devoted to destruction by the edge of the sword all in the city, both men and women, young and old, oxen, sheep, and donkeys.

22 Joshua said to the two men who had spied out the land, "Go into the prostitute's house, and bring the woman out of it and all who belong to her, as you swore to her."

23 And the young men who had been spies went in and brought Rahab out, along with her father, her mother, her brothers, and all who belonged to her. They brought out all her clans, and they set them outside the camp of Israel.

24 They burned down the city and everything in it.

Only the silver and gold, and the vessels of bronze and iron, they put into the treasury of Yhwh's house.

25 But Rahab the prostitute, with her family and all who belonged to her, Joshua spared. She has lived in the midst of Israel ever since. For she hid the messengers whom Joshua sent to spy out Jericho.

26 At that time Joshua made an oath: "Cursed before Yhwh be anyone who tries to rebuild this city, Jericho. At the cost of his firstborn he shall lay its foundation, and at the cost of his youngest he shall set up its gates!" So Yhwh was with Joshua, and his fame spread throughout the country.

We will touch upon several notable features of this second episode, yet before doing so, we need take a closer look at the first episode - the account of Rahab hiding two Israelite spies, lying to the king, and then negotiating protection for herself and her family. 


\section{A CITY BESIEGED}

Strangely, the Rahab story has nothing to say about the spies' activities of scouting or espionage. The first episode begins with Joshua secretly dispatching the men with orders to "go view the land and Jericho." However, when the men go, the only thing they manage to do is "enter the house of a prostitute named Rahab and spend the night there" (2:I). ${ }^{\mathrm{I}}$ The king learns that Israelites had infiltrated the city with the intention of "searching out the whole land." He quickly establishes that they are residing in Rahab's place and sends soldiers to seize them there.

The succinct narration in 2:I-7 shows, rather than reports (as in vv. 8-I4), the heightened state of alarm that Israel's arrival had provoked among the inhabitants of Jericho. Despite the precautions that Joshua and the spies take to conduct a clandestine mission, their arrival doesn't go unnoticed. The narrator implies that all the inhabitants of the country are well aware of Israel's presence on Canaan's eastern border and nervous about an imminent invasion.

This is precisely what Rahab spells out to the spies in an extended scene that stands at the center of the account:

But before [the two spies] lay down, she came up to them on the roof. Then she said to the men: "I know that Yhwh has given you the land, and that dread of you has fallen on us, and that all the inhabitants of the land are faint because of you. For we have heard how Yhwh dried up the water of the Red Sea before you when you came out of Egypt, and what you did to the two kings of the Amorites that were beyond the Jordan, to Sihon and Og, whom you utterly destroyed. When we heard it, our hearts melted. No longer does a spirit rise in any man because of you! Yhwh your god is indeed god in heaven above and on earth below. "Now then swear to me by Yhwh - for I have dealt kindly with you; you in turn must deal kindly with my father's house and give me a sure sign - that you will spare my father and mother, my brothers and sisters, and all who belong to them, and deliver our lives from death." The men said to her, "Our life for yours! If you do not tell this business of ours, then we will deal kindly and faithfully with you when Yhwh gives us the land." ${ }^{4}$ Josh. 2:8-I4

${ }^{13}$ On the comedic qualities of the story, see Chapter 7, n. 33 .

${ }^{14}$ It's possible that the first line (v. 8) was added at a later point to make the scene a flashback, taking place "before they lay down." (The verb is the same as that used at the end of verse I.) Notice that the spies agree to spare Rahab's life on condition that she does not tell anyone about what they were up to. Had the conversation taken place after she speaks to the king, this condition would not make sense: Wasn't Rahab's act of hiding the men and deceiving the king already enough to merit the protection she solicits here? 
This scene is likely secondary. As scholars have long observed, the first part of story (vv. I-7), which ends with Rahab sending the pursuers on a wild-goose chase, continues naturally in the description of Rahab letting the spies down on a rope from her window (Vv. I 5-I6, 2I-23):

I Then Joshua son of Nun sent two men secretly from Shittim as spies, saying, "Go, view the land, and Jericho." So they went and came to the house of a prostitute whose name was Rahab, and they spent the night there. 2 It was told to the king of Jericho: "Some men have come here tonight from the children of Israel to search out the land." 3 Then the king of Jericho sent orders to Rahab, "Bring out the men who have come to you, who entered your house, for it is only to search out the whole land that they have come." 4 But the woman took the two men and hid them. Then she said, "True, the men came to me, but I did not know where they are from. 5 When it was time to close the gate at dark, the men left. I do not know where the men went. Pursue them quickly, for you can overtake them." [6 She had, however, brought them up to the roof and hidden them with the stalks of flax that she had spread out on the roof.] 7 So the men pursued them on the way to the Jordan as far as the fords. As soon as the pursuers had gone out, the gate was shut.

[vv. 8-I4]

I 5 Then she let them down by a rope through the window, for her house was in the city wall, and in the city wall she resided. I6 She said to them, "Make for the hills so that the pursuers do not chance upon you. Hide there for three days until the pursuers return, and then go your way.” ...2 I Thereafter she let them go, and they left. [She tied the crimson cord in the window.] 22 They left and they went into the hill country and stayed there three days, until the pursuers returned. The pursuers had searched all along the way and found nothing. 23 Then the two men returned and came down again from the hill country crossed over, and came to Joshua son of Nun, and told him everything that had happened to them. [24 They said to Joshua, "Yhwh has delivered the whole land into our hands, and indeed all the inhabitants are faint because of $u s$.]

Not only does the scene in verses 8-I 4 sever the narrative at this juncture; its language and ideas stand out as an anomaly in the context of the chapter. Acclaiming Yhwh's hand in Israel's history, Rahab uses formulations and concepts that presuppose an advanced stage in the formation of the wider biblical narrative, as we saw in our discussions of Sihon and Og ("two Amorite kings," vv. 8-I4) in Parts I and II. The only other place in the account where we find this language is the final line (v. 24), which appears to have been composed as a new conclusion that integrates Rahab's exact words into the spies' debriefing. ${ }^{15}$

I5 The older conclusion in verse 23 focuses on what had happened to the spies at Jericho. The addition of verse 24 shifts the attention to the contents of Rahab's declaration, which describes the angst that had pervaded the entire land. 
The second part of verse 2I, which presents Rahab hanging a crimson cord from her window, interrupts the flow of the narrative and is easy to identify as an editorial gloss. It presupposes the supplementary material related to the logistics of Rahab's rescue (vv. 8-I4 + I7-2I). ${ }^{\mathrm{I} 6}$

The announcement in verse 6 that Rahab had concealed the spies on the roof provides an additional clue that the scene in verses $8-\mathrm{I} 4$ is secondary. The narrator has already reported in verse 4 that "the woman took the two men and hid them." (Where she hides them is not said.) While verse 4 flows effortlessly in the narrative and must be part of the earliest version, the announcement in verse 6 is poorly placed. It was likely added by the same hand that composed verses 8-I4, which begin with Rahab going up to the men on the roof.

The Masoretic text at 2:4 is literally "she hid him," and the unexpected singular may be an echo of Exodus 2:2, where Moses's mother "hid him" (using the same verb). Just as the story of the exodus begins with the courageous defiance of the Egyptian king by Moses's mother as well as by his sister and the Hebrew midwives, the story of the conquest begins with the courageous defiance of a Canaanite king by a woman. In each case, the women not only act without the help of males but also protect them as passive objects. These parallels may help us understand why later scribes seized on the originally brief account and embellished it: without husband and children, Rahab works maternally to protect the spies, covering them under her stalks of flax and then lying to the king's men as to their whereabouts. Moreover, the description of her letting the spies down by a rope brings to mind the scene in I Sam. I9 in which Michal lets David down by a rope from her window when he, like the spies, is fleeing for his life from a king. In keeping with an assault on hegemonic masculinities that can be identified in many biblical texts, these narratives undermine pretensions of male self-sufficiency by depicting valiant women acting surreptitiously. In their crucial contributions to the nation's history, they orchestrate directly, and physically, the lives of male figures. ${ }^{17}$

${ }^{16}$ Notice the Wiederaufnabme of "they left" in verses $2 \mathrm{ra}$ and 22a. On the secondary nature of the logistics and reference to the crimson cord, which has inspired Christian allegorical readings, see Kratz, Composition, $20 \mathrm{I}$.

17 We revisit this point in relation to the book of Judges in Part IV. On Rahab as a queer figure who lives on the margins and sees and acts differently from those in her society, see Erin Runions, "From Disgust to Horror: Rahab's Queer Affect," Postscripts, 4 (2008), 4I-69; Billy Klutz, "Queers in the Borderlands: Rahab, Queer Imagination, and Survival," The Other Journal, September 2I, 20I 5, https://theotherjournal.com/20I 5/O 
While the scene in verses $8-\mathrm{I} 4$ is most likely supplementary, Rahab's statements in it about the fear that had consumed Canaan are consistent with the rhetorical purpose of the older account. We are told in verse 7 that as soon as the men took off in pursuit of the spies, the city gate was closed after them. Israel's arrival obviously had struck fear into the heart of Jericho's inhabitants and king. Likewise, chapter 6 begins by reporting that Jericho was on lockdown, which Yhwh interprets as a portent of the city's imminent downfall:

Jericho was shut up tightly because of the Israelites; no one went out and no one came in. Yhwh said to Joshua, "See, I have handed Jericho over to you, along with its king [and soldiers]. You shall march around the city, all the warriors surrounding the city ...." Josh. 6:I-3

Before the composition of all the disparate material related to the crossing of the Jordan in chapters $3-5$, the Rahab story would have segued directly into the battle account. The latter tells how Jericho was "shut up tightly because of the Israelites," and the Rahab story provides a glimpse from the inside on why this was so.

The battle account focuses on the city's wall. The remains of an impressive system of fortifications at Jericho could be seen be passers-by in antiquity, and they can still be witnessed today. Although the city was conquered in the sixteenth century BCE during an Egyptian campaign in the region, the authors of the biblical account point to the ruins as physical evidence for - and a monument to - Israel's inaugural triumph after invading Canaan. This historiographical purpose explains why the authors do not present Joshua engaging the enemy in the field, as he does at $\mathrm{Ai}$ in the immediately following episode. ${ }^{\mathrm{I} 8}$

9/2I/queers-in-the-borderlands-rahab-queer-imagination-and-survival/. On Rahab and Michal, see Adriane Leveen, Biblical Narratives of Israelites and Their Neighbors: Strangers at the Gate (New York: Routledge, 2017).

I8 The account of the battle at Ai has its own commemorative-historiographical function namely, to explain "the great heap of stones that until this day still stands there," with the location being described as "the entrance of the city gate." This is likely the original reference in the name "Ai," and 8:29b, which describes the city as an "eternal tell of desolation," is likely a product of a later reworking that brings the account in line with the demolition of Jericho in chapter 6. (Notice also the supplementary character of 8:2a and $8: 8$.) The Achan story in chapter 7 is, as most agree, a late preface to the older battle account in chapter 8 . On the premeditated and deliberate destruction of these and other cities, including their iconic architecture and memories, see Jacob L. Wright, "Urbicide: The Ritualized Killing of Cities in the Ancient Near East" in Saul Olyan (ed.), Ritual Violence in the Hebrew Bible (New York: Oxford University Press, 20I 5), I47-I66. 
If the first and most basic purpose of the Rahab story is to explain why Jericho was "shut up tightly," and therefore why the nation attacks the city in an unconventional manner, we can explain why the spies, instead of continuing their espionage activities, immediately make their way back to Joshua and "tell him everything that had happened to them" (2:2I). ${ }^{\text {I9 }}$ They terminate their reconnaissance mission because it had already provided them with all the intelligence they needed: panic had seized Jericho, and as Yhwh spells out for Joshua, this panic is handwriting on the wall that the city would soon fall.

\section{EDIFICATION OF A DEFEATED NATION}

The aim of the espionage mission, as I pointed out in Chapter 7, was not to inspect the military establishments in Canaan but to assess the psychological state of the local population. This aim explains why the spies visit the house of Rahab. Due to her private intercourse with diverse clientele, the proprietresses of bordellos and taverns were privy to news and rumors from abroad and intimately aware of the locals' disposition. For example, according to Hammurabi's laws, "if criminals [or conspirators] plot in the house of a tavern keeper [sabitum], and she does not capture those criminals and deliver them to the palace, the tavern keeper shall be put to death." 20

Presupposing these associations, the supplements to the story portray Rahab approaching the Israelite men before they go to sleep. She divulges to them that the land's inhabitants were shaking in their sandals in fear of Israel and its god. Her statement divulges the deflation of Canaan's male inhabitants: "When we heard it, our hearts melted. No longer does a spirit rise in any man because of you! Yhwh your god is indeed god in heaven above and on earth below." 2 I

Signs, oracles, prophetic performances, speeches, and rituals that motivate the army or its leaders for an impending engagement are all important features of biblical war commemoration. In addition to serving an immediate narrative function, this discourse on fear and courage has a larger didactic purpose. Thus, Rahab's reference to the memories of Sihon's and Og's defeat resembles the use Moses makes of these same memories throughout Deuteronomy, as he rouses the nation on the eve of

19 The Hebrew literally means all that had found them, which is a play on the pursuers searching for them (see vv. 5, I6 and 22).

${ }^{20}$ Law ro9. See Dixon, "Saloons." ${ }^{21}$ See n Chapter 7, n. 29. 
war. ${ }^{22}$ Like Moses's orations in Deuteronomy, a new ending to the Rahab story plays a rhetorical role by having the spies draw a conclusion for Joshua: "Yhwh has given the entire land into our hands; indeed, all the inhabitants of the land melt in fear before us!"

Two chapters from the book of Numbers tell of the initial scouting mission conducted by the preceding generation soon after leaving Egypt. The spies' objective was to find, and to bring back to the national assembly, a sign confirming that Israel would claim certain victory. Likely composed much later than the first iteration of the Rahab story, the account in Numbers differs from this story above all in the failure of the mission. The scouts bring back an "evil report" that demoralizes the nation, and, as punishment, Yhwh sentences the entire generation to death in the wilderness. Paralyzed by fear, the nation stands no chance of victory. The same goes conversely for their enemies, and such is the case as a new generation prepares to invade angst-filled Canaan in the time of Rahab. If even this non-Israelite knew that Canaan was about to be wiped out, all the more reason for Israel to eschew disbelief, which had brought forty years of wandering in the wilderness.

More than any other biblical account, the story of Gideon from the book of Judges is characterized by a profusion of prebattle signs and oracles. Its distinctive quality is due to the work of later scribal hands that transformed a "mighty hero" into an exceedingly trepidatious farmer. ${ }^{23}$ At every step of the way, Gideon needs signs and demonstrations that he and his men could overpower the enemy. On the eve of battle, the fretful warrior goes down with his servant on a reconnaissance mission into the enemy camp. There, they overhear a soldier describing his dream about the collapse of a tent, which his fellow interprets as a portent of their own defeat: "This is nothing other than the sword of Gideon ben Joash, a man of Israel. Into his hand God has given Midian and all the army!" Gideon had already witnessed many signs that he would triumph over the Midianites and this last sign is what finally emboldens him to begin the battle (Judg. 7:IO-I 5 ).

As we observe in the Gideon account, the news brought by the spies in the Rahab story galvanizes Joshua's resolve on the eve of invasion. The

${ }^{22}$ Moses refers to them throughout chapters 2-4 and then resumes this theme in 29:6 and $3 \mathrm{I}: 4$. The eve-of-battle addresses provided the framework in which later scribes inserted the Deuteronomic law code (parts of which are much older than the speeches).

${ }^{23}$ I treat this scribal transformation in "The Evolution of the Gideon Narrative" in Saul M. Olyan and Jacob L. Wright (eds.), Supplementation and the Study of the Hebrew Bible (Providence: Brown Judaic Studies, 2018), I05-I 24. 
nation's leader has already received an oracle of divine encouragement (I:I-9) and will witness yet another divine sign right before the battle (5:I3-I 5). ${ }^{24}$ The character of Joshua does not suffer from Gideon's lack of courage; to the contrary, he, like Rahab, is a paragon of valor.

The intended audience of our texts would have been faced with the prospect, and then the fact, of forfeiting to foreign armies the land Joshua had conquered. These texts were written and rewritten for the edification of a defeated nation, and as such, they participate in an elaborate biblical discourse on faith and fear. ${ }^{25}$

\section{BELIEF AND ACTION}

According to Klaus Bieberstein, a Roman Catholic biblical scholar from Germany, the authors of the Rahab story highlighted the harlot's "confession of faith" and placed it at the center of the account as an illustration of Isaiah's verdict "If you do not believe, you will not stand" (Isa. 7:9). ${ }^{26}$ Because Rahab believes, she survives, becoming thereby a living "monument" (Denkmal) that witnesses to the nexus between faith and salvation. Bieberstein agrees that the Rahab story participates in a struggle to define Israel's collective identity, yet it does so, according to his interpretation, by pointing to verbal confessions and "faith/belief" (Glaube) in Yhwh as the basis for belonging.

While this reading may be consistent with influential iterations of Christian theology, it's difficult to reconcile with the logic of the text itself. Belief isn't the condition for Rahab's rescue, let alone her inclusion among the people of Israel. To be sure, the biblical scribes portray Rahab as being confident that Israel will conquer the land, and this confidence stands out

${ }^{24}$ The oracle in I:I-9 has been secondarily prefaced to the older introduction in I:IO-II (pace Germany, Exodus-Conquest Narrative, 3 I4-3 I 8). It has grown in stages, serving as a preamble to not only the conquest story but also (various editions of) the Former Prophets (Joshua to Kings). Joshua 5:I3-I 5 was likely inserted between the Rahab story and the battle account as yet another sign to Joshua that Jericho would certainly fall, since the captain of Yhwh's army was present. Due to several obvious parallels between this story and that of Moses's commission in Exodus 3, it seems reasonable to interpret the two texts as a scribal attempt to connect Joshua and the conquest of Canaan to Yhwh's first apparition to Moses and his promise to bring Israel to a new land.

${ }^{25}$ I treat the subject of fear with Sara Kipfer in "Fear (not)! Emotion and Ethics in Deuteronomy," Journal of Ethics in Antiquity and Christianity (forthcoming).

${ }^{26}$ Klaus Bieberstein, Josua - Jordan - Jericho: Archäologie, Geschichte und Theologie der Landnahmeerzählungen Josua I-6 (Göttingen: Vandenhoeck \& Ruprecht, I995). When it's not isolated from its context, this oft-quoted line from Isaiah can hardly bear the theological weight it is frequently forced to carry. 
against the account of the first espionage mission during the days of Moses. At that time, Yhwh condemned an entire generation to die in the wilderness for its lack of faith:

And Yhwh said to Moses, "How long will this people spurn me, and how long will they not believe (in) me [and] all the signs I performed in their midst." Num. I 4:I I

Here, as elsewhere, Israel's refusal to believe in Yhwh's power elicits divine punishment. It would be a flagrant non sequitur, however, to conclude that these texts identify faith as the criterion for membership, as if Israel were a "community of believers."

Twice in the second episode of the Rahab story, the authors name the heroine's actions in hiding the spies as the reason for the special treatment she - together with all her family and clans - receives from the conquerors $(6: 17 \mathrm{~b}, 25 \mathrm{~b})$. Even if these lines are late additions to the account, one must explain why their authors did not mention the words she spoke as a testimony to her belief in Israel's god. It might be argued, in line with the early Christian writings discussed in Chapter 7, that Rahab's underlying faith prompted her to hide the Israelite men. Even so, the account in Joshua identifies solely her deeds as the grounds for her and her family's salvation; in stark contrast to many later interpreters, it says nothing about these works as tangible testaments to her "faith."

Rahab's report about the fear that had engulfed the local population culminates in a declaration: "Yhwh your god is indeed god in heaven above and on earth below." (2:I I b; cf. Deut. 4:37-39). As we noted in Chapter 7, these words resemble the avowals of Jethro and Naaman. All three figures do not simply state the facts; they also express solidarity. Even if Jethro returns to his own country instead of joining the people of Israel, his declaration reinforces the special quality of his relationship to the nation, which is celebrated in the rituals of commensality with its leaders (Exod. I 8:I2). ${ }^{27}$ Rahab's statement about Israel's god, in the same way, does not in and of itself qualify her for inclusion among the people of Israel. But if she is to be included, she must both demonstrate her loyalty through her

27 In Part IV, we examine the Jethro story in relation to the Kenites as "fellow travelers" with Israel. On the commonalities between Rahab and Jethro in rabbinic imagination, which imagines them as equally promiscuous in their respective roles as prostitute and priest, see David J. Zucker and Moshe Reiss, "Judaism's First Converts: A Pagan and a Prostitute," TheTorah.com website, https://thetorah.com/judaisms-first-converts-a-pa gan-priest-and-a-prostitute/ [20I7]. 
actions and interpret them with her words. (Her statement likely belongs to the same compositional level as the lines added to Joshua 6 that describe the honored place she assumes in the nation.)

Consider again the example of Ruth. When Boaz grants special privileges to this Moabite, she is taken aback and wonders why. Boaz responds by pointing to her record of solidarity with Naomi and, by extension, with the people of Israel as a whole:

All that you have done for your mother-in-law since the death of your husband has been fully told to me, and how you left your father and mother and your native land and came to a people that you did not know before. May Yhwh reward you for your deeds. And may you have a full reward from Yhwh, the god of Israel, under whose wings you have come for refuge!” Ruth 2:I I-I 2

As in Rahab's case, Ruth's reward, both from Boaz and from Yhwh, is merited by her deeds, whereas the words she speaks to Naomi at the beginning of the narrative are the means by which she proclaims her intent and motivation. Even if they are indispensable, they are not the grounds for her inclusion.

In Chapter 7, we compared Rahab's statement to the testimonies and oaths of loyalty required for naturalization in modern nationstates. The difference is that Rahab's testimony revolves around Israel's deity; today, one swears allegiance to a flag. This difference turns out to be not so stark if we remember that the national flags of modernity evolved as secularized incarnations of the deities and religious symbols under whose aegis ancient states operated. The project of peoplehood that the biblical writers conceived has a thoroughgoing theological dimension. The fact that the biblical writers ascribed a central role to their deity does not mean, however, that the form of peoplehood they envisioned is more akin to an assembly of believers than a national body. Even so, a deity that transcends political divisions offered an ideal common point for competing communities to consolidate as one people and form a more perfect union (see the discussion in Part IV).

\section{A NEW COVENANT}

The complexity of Rahab's identity may be embedded already in the earliest formulations of the account, but as the story evolved, the intertextuality with other biblical texts assumed a sharper profile. We notice this not only in Rahab's testimony but also in her extended negotiations 
with the spies. ${ }^{28}$ It's obvious to Rahab that no one stands a chance of surviving the impending devastation and that Canaan's future clearly lies with Israel. Hence, she not only hides the men but is also eager to persuade them to make a pact with her. She fears that Israel would annihilate her entire family, and we, as readers, know this is what they are about to do, in keeping with the command in Deuteronomy to annihilate all the Canaanites (see Deut. 7 and 20).

Many passages in Joshua do not reflect knowledge of Deuteronomy, and the earliest portrait of Rahab did not present her Canaanite identity as grounds for execution. The present shape of the book, however, is explicitly and repeatedly linked to its predecessor. For example, the Gibeonite account (chaps. 9-10), which we explore in Chapter 9, presupposes the command to annihilate the Canaanites. In this narrative framework, the final form of the Rahab story demonstrates the possibility of suspending the Mosaic decree in the case of someone who stands in undivided solidarity with Israel and proves his/ her loyalty when push comes to shove.

The scribes who reworked the account devoted a lot of space to the oath that Rahab demands from the spies (2:8-I4, I7-2I; see also 6:22), and the reason seems to be that they wanted to address the way in which Rahab becomes part of Israel. Their account reveals paradigmatically how a non-Israelite secures protection and privileges via a proven record of loyalty (notice the length and shrewdness of her lines to the king's men), which merits a contractual guarantee in the form of an unbreakable oath. Prompting their editorial work was the insight that eloquent affirmations about the power of Israel's god, and even courageous displays of loyalty, are of limited value if they do not culminate in legally binding guarantees

${ }^{28}$ Notice how the spies' statement about the oath (Josh. 2:I4, 20) is cut asunder by a lengthy section (vv. I5-I9) that fleshes out the dramatic meat on the skeletal narrative. Interrupting them mid-sentence, Rahab sends the two men away with directions on how to elude the king's soldiers. But after she lets them down from her window, they continue their instructions, speaking now at much greater length (vv. I7-20). Later, we read that she "let them go" (v. 2I, 23*), without reference to either the window of her house or the wall (cf. v. I 5 ).

When later readers, such as Josephus, retell the story, they fill in its gaps by reporting that the men first came to Jericho, surveyed its fortifications, and then only later entered the house of Rahab. Of course, they simplify the lengthy departure scene and harmonize its many contradictions. Aside from being fascinating subjects for study in their own right, these retellings help us in reconstructing the prehistory of biblical accounts, for it is often the case that we fail to notice important diachronic clues in these accounts until we compare them with their retellings. 
of protection. Such pledges define and formalize the mutual obligations that constitute the bedrock of a political community. ${ }^{29}$

When creating this complex account, the scribes couldn't help but echo Sinai. Throughout Exodus and Deuteronomy, Yhwh appeals to a record of protecting and saving the nation as the basis for the covenant he makes with the nation. Similarly, Rahab begins by recalling these same salvific deeds of Yhwh (2:9-I I), and then makes a case for her own covenant with the nation (beginning with the appropriate formula "and now," 2:I2). In making her case, Rahab invokes her act of "loyalty/hospitality" (hesed). Since she risked her life and the lives of her family to save the spies, they now should reciprocate with a quid pro quo, swearing to show her "loyalty" and to "save" her and her family (2:I2-I3).

In making this new covenant, Rahab demonstrates superb negotiation skills, and perhaps we are to understand that she owes these skills to her profession. The pact with the Israelite men is just as much about her (and her family's) survival as transactions with clients. The difference is that the former is more enduring and transformative, as she now moves from the margins of one society to the center of another.

\section{INCLUSION VERSUS INTEGRATION}

We established that Rahab's belonging presupposes both her deeds and her words. But what more can we say about the nature of the belonging that she procured? In Chapter 7, we saw how Josephus and the rabbis claimed that she was fully integrated into Israelite society, eventually marrying Joshua and becoming the ancestress of important figures in the nation's history, and the Gospel of Matthew does something similar by grafting her into the family tree of Jesus. Thus, both Jewish and Christian readers imagine Rahab being fully integrated into the life of the nation, but does the account in Joshua suggest that she became a full-fledged member of Israel?

We are told that the spies, after following through with the pact and rescuing Rahab's family, "left them outside the camp of Israel" (6:23). Although they are no longer a part of the city destined for destruction, they are kept separate from the rest of the nation and not allowed to dwell

29 See the important study of the subject by Michael Walzer, Obligations: Essays on Disobedience, War, and Citizenship (Cambridge, MA: Harvard University Press, I970); as well as the critical review by Robert Horowitz, "Obligations: Essays on Disobedience, War, and Citizenship," Cornell Law Review, I7 I (I970), I7I-I75. 
alongside its members. This line, as I suggested earlier, is likely a gloss added by a priestly scribe who was disturbed by the notion that a Canaanite harlot and her family could have so easily entered the (sacred) space of the camp and thereby jeopardized Israel's welfare. In contrast to this gloss, the final statement about Rahab proclaims resoundingly:

As for Rahab the prostitute, and the house of her father, and all that belonged to her, Joshua saved them alive; she lives in Israel's midst to the present day, because she hid the messengers Joshua had sent to spy out Jericho. Josh. 6:25

If Rahab came to live in Israel's midst, are we to understand that she became a full-fledged member of the nation?

The term "midst" is used often in the book, recurring at key moments in the narrative: Yhwh performs wonders in the Israelites' midst at the crossing of the Jordan (3:5) and proves that he dwells in their midst by driving out the seven nations that dwell in the Promised Land (3:10). Israel sets up a monument in the nation's midst for future generations (4:6). In the episode that immediately follows the statement about Rahab, a figure named Achan wrongly keeps some of the war spoils for himself; because these banned items were found in Israel's midst, they cause a devastating defeat for the nation (7:I2-I3). That many indigenous outsiders, like Rahab, dwell in their midst is affirmed in the account of Joshua reading the words of Moses to the assembly $(8: 35)$. The account of the Gibeonites in chapters 9-Io plays heavily on this theme. It presents a population that lives in Israel's midst tricking the people into thinking that they were actually from far away $(9: 7,16,22)$. By means of such subterfuge, they make peace with the Israelites and secure rights to continue dwelling in their midst (IO:I). In addition to Rahab and the Gibeonites, others continue to live in Israel's midst because various tribes failed to drive them out (I3:Io, I6:Io). Finally, in his valediction, Joshua implores Israel to put away the foreign gods that are in their midst (24:23).

The term "midst" is thus used in Joshua in reference to things that are separate from Israel while having an intimate relationship with it whether deities or proscribed war spoils. When applied to peoples and populations, the term does not suggest that the group has become one with Israel. The statement about Rahab may suggest, then, that she was embraced into Israelite society and given an honored place in Israel's national memory, even while not becoming a full Israelite. But given that, ideally, the deity dwells in the midst of Israel, the use of the term is likely used here to draw attention to the place of honor Rahab occupies in the nation. This brings to mind Moses's father-in-law, whose story we 
treat in Part IV. An outsider too, he should join the nation as a fellowtraveler, serving as its "eyes" and seeking out places where it should camp; the place he is offered is at the head of the camp, with the deity leading the nation through the wilderness (see Num. I0:29-32, 33-36). What makes Rahab special, however, is that she still occupies her privileged place "until the present day."

The sociological distinction between inclusion and integration proves useful here. If Rahab and her family were included within Israel without being fully integrated, they could be recognized as a group with a protected and privileged status. Such seems to have been the case with the Gibeonites. By means of a formal pact, the Israelites pledge that they will not annihilate this population, and they guarantee its members sanctuary within their society. The book of Samuel presents King Saul violating this oath when he "attempts to wipe out [the Gibeonites] in his zeal for Israel and Judah," and the bloodguilt incurred by this king eventually results in a famine that Yhwh inflicts upon Israel. Given several points of overlap with the Rahab account, these Gibeonite texts merit a closer examination, which we undertake in Chapter 9. 